\title{
Application of a Biomimetic Sensor Based on Iron Phthalocyanine Chloride: 4-Methylbenzylidene-Camphor Detection"
}

\author{
Ana Carolina Boni, ${ }^{a}$ Maria D. P. T. Sotomayor, ${ }^{a}$ Marcos R. V. Lanza, ${ }^{b}$ \\ Sônia Maria C. N. Tanaka ${ }^{c}$ and Auro A. Tanaka*,c,d
}

${ }^{a}$ Departamento de Química Analítica, Instituto de Química, Universidade Estadual Paulista,
14801-970 Araraquara-SP, Brazil

${ }^{b}$ Departamento de Química e Física Molecular, Instituto de Química de São Carlos, Universidade de São Paulo, 13560-970 São Carlos-SP, Brazil

'Departamento de Química - CCET - Universidade Federal do Maranhão, 65085-580 São Luís-MA, Brazil

'Instituto Nacional de Ciência e Tecnologia de Bioanalítica, 13083-970 Campinas-SP, Brazil

\begin{abstract}
A construção e a aplicação de um sensor biomimético para a determinação de 4-metilbenzilideno cânfora (4-MBC), um protetor de radiação ultravioleta (UV), são descritas. O sensor foi preparado pela modificação de um eletrodo de pasta de carbono com um complexo de cloreto de ferro(III) com ftalocianina, $\mathrm{FePcCl}$. As medidas amperométricas conduzidas com o sensor, sob um potencial aplicado de 0,0 V vs. Ag|AgCl em uma mistura de tetraidrofurano e 0,1 $\mathrm{mol} \mathrm{L}^{-1} \mathrm{H}_{2} \mathrm{SO}_{4}$ (30:70 em volume), mostraram uma resposta linear no intervalo de $1,8 \times 10^{-4}$ to $9,0 \times 10^{-4} \mathrm{~mol} \mathrm{~L}^{-1}$. Uma investigação detalhada da seletividade da resposta frente a outros nove filtros UV também foi realizada. Um mecanismo de resposta do sensor foi proposto e os resultados para a quantificação de 4-MBC em protetores solares comerciais e em águas de piscinas e de rios são apresentados.
\end{abstract}

The construction and application of a biomimetic sensor for determination of 4-methylbenzylidene camphor (4-MBC), an ultraviolet (UV) radiation protector, are described. The sensor was prepared by modifying a carbon paste electrode with iron(III) phthalocyanine chloride ( $\mathrm{FePcCl})$. Amperometric measurements carried out with the sensor under an applied potential of $0.0 \mathrm{~V} v \mathrm{~s}$. $\mathrm{Ag} \mid \mathrm{AgCl}$ in a mixture of tetrahydrofuran and $0.1 \mathrm{~mol} \mathrm{~L}^{-1} \mathrm{H}_{2} \mathrm{SO}_{4}$ solution (30:70 volume ratio) showed a linear response range from $1.8 \times 10^{-4}$ to $9.0 \times 10^{-4} \mathrm{~mol} \mathrm{~L}^{-1}$. A detailed selectivity investigation for other nine UV filters was also performed. A sensor response mechanism was proposed and the results for 4-MBC quantification in commercial sunscreens and in water from swimming pools and rivers are presented.

Keywords: iron phthalocyanine, amperometric sensor, methylbenzylidene camphor

\section{Introduction}

Chemical ultraviolet (UV) filters have been introduced in 1889, when an acidified quinine sulfate solution was used to block UV radiation, ${ }^{1}$ and thereafter sunscreen has become an everyday cosmetic with continuously increasing use.

The positive effect exerted by UV filters is to block the UV light radiation damage from sunlight, sunlamps

*e-mail: tanaka@ufma.br

\#Dedicated to the memory of our friend Professor Ícaro Sousa Moreira, DQOI-UFC, Brazil and in tanning parlours; moreover, they have color protective abilities and therefore may prevent premature fading of hair color and damage to hair cuticle. On the other hand, it has been recently reported that commonly used chemical UV filters may cause endocrine disrupting effects in both aquatic and terrestrial animals, as well as in human skin cells. ${ }^{1-4}$ In addition, five of the most commonly UV filters used in cosmetic formulations, i.e., oxybenzone, octyl methoxycinnamate (OMC), homosalate, $p$-aminobenzoic acid (PABA), octyldimethyl-PABA (ODP), and 4-methylbenzylidene camphor (4-MBC), exhibited oestrogenic effects in MCF-7 (Michigan 
Cancer Foundation-7) breast cancer cells. Furthermore, oxybenzone, 4-MBC and OMC were confirmed to be oestrogenic by classical in vivo uterotrophic assays with rats dosed in the feed. For the most potent oestrogenic UV filter 4-MBC, the effect could be even replicated by application on rat skin, resembling human exposures with sunscreen cream. In vitro studies have shown other hormone disruption responses (anti-oestrogenic, androgenic, antiandrogenic and progestogenic activities) for almost all the chemical UV filters used in sunscreen formulations. ${ }^{5,6}$

Recent publication ${ }^{1}$ has shown that, in Denmark, urban water is the primary recipient of six UV filters, including oxybenzone, avobenzone, 4-MBC, octyl methoxycinnamate, ODP and homosalate, with estimated 8.5-65 tonnes and 7.1-51 tonnes in wastewater and surface water, respectively. In North of China, it has been observed that the levels of benzophenone-3 (BNP), 4-MBC, OMC and octocrylene (OC) in different units of wastewater plants were in the concentration range $2.13-34.0 \mathrm{ng} \mathrm{L}^{-1}$, with high concentrations in hot seasons. ${ }^{7}$

Since the use of UV filters in countries like Brazil is expected to continuously increase, and the disposal of such compounds in aquatic environments is still not regulated by any government agency, it seems worthwhile to apply the knowledge in biomimetic sensors based on metalophthalocyanines and metaloporphyrins for detection of UV filters, more specifically 4-MBC, which is commonly used in sunscreens for children.

Metalophthalocyanines and metaloporphyrins have been widely employed in sensor construction with different transducer systems, such as optical, ${ }^{8-13}$ chemoresistive, ${ }^{14-18}$ impedimetric, ${ }^{19}$ piezoelectric ${ }^{20,21}$ and mainly electrochemical, ${ }^{22-30}$ since they present high electrocatalytic activities for many redox reactions. In addition, enzymeless sensors $^{31,32}$ using these macrocycles ${ }^{33-38}$ as biomimetic active sites of redox enzymes, as peroxidase, ${ }^{34,37}$ dopamine monooxigenase ${ }^{38}$ and $\mathrm{P} 450^{35,36}$ have been described, offering a real and an alternative tool to official analytical methods. Furthermore, it is well known that established methods for identifying pollutants usually require preparative steps and expensive equipments, such as high performance liquid chromatography (HPLC) and mass spectrometry (MS), and the development of alternative methods for selective, sensitive, quicker and cheaper analyses would be welcome.

\section{Experimental}

\section{Chemicals and solutions}

All chemicals used were of analytical or HPLC grade. Iron(III) phthalocyanine chloride $(\mathrm{FePcCl})$, p-aminobenzoic acid (PABA), octyldimethyl-PABA (ODP), 4-methylbenzylidene camphor (4-MBC), [3-(4-methylbenzylidene)bornan-2-one], isoamyl p-methoxycinnamate (IMC) and 2-phenyl-5benzimidazolesulfonic acid (PBS) were acquired from Aldrich. Benzophenone-3 (BNP); octylmethoxycinamate (OMC); menthyl anthranilate (MA); octyl salicylate (OSA) and avobenzone (AVB) were purchased from Fluka. Tetrahydrofuran (thf), acetonitrile $(\mathrm{MeCN})$ and sulfuric acid were obtained from Synth, Brazil.

The 4-MBC standard solutions were prepared in thf for the electroanalytical experiments and in the respective mobile phase for the HPLC experiments.

\section{Sensor construction}

In order to obtain homogeneously modified carbon pastes, the sensor was prepared by mixing an adequate amount of $\mathrm{FePcCl}$ with graphite powder and $1.0 \mathrm{~mL}$ of $0.1 \mathrm{~mol} \mathrm{~L}^{-1}$ phosphate buffer solution ( $\mathrm{pH}$ 7.0). After drying at room temperature, $50 \mu \mathrm{L}$ of mineral oil were added and mixed to obtain a homogeneous paste, which was placed into the cavity of a glass tube ( $4 \mathrm{~mm}$ internal diameter and $1 \mathrm{~mm}$ depth) with a platinum slide inserted for electrical contact with the paste. The effect of the FePcCl content on the sensor response was evaluated by preparing five different pastes with the macrocycle weight percentage varying from 5 to $15 \%$.

\section{Electrochemical measurements}

The electrochemical experiments were conducted, at room temperature, in solutions containing a 70:30 volume ratio of $0.1 \mathrm{~mol} \mathrm{~L}^{-1} \mathrm{H}_{2} \mathrm{SO}_{4}$ and thf, respectively, and using a conventional three-electrode cell with the modified carbon paste electrode as working electrode, $\mathrm{Ag} \mid \mathrm{AgCl}$ electrode and platinum wire as reference and counter electrodes, respectively. All experiments were carried out in air-equilibrated solutions, since preliminary experiments have shown that dissolved oxygen did not interfere in the sensor response. The data acquisition was performed with a PalmSens potentiostat (Palm Instruments BV, Netherlands) interfaced with a microcomputer.

The amperometric measurements were carried out at a previously optimized potential of $0.0 \mathrm{mV} v s . \mathrm{Ag} \mid \mathrm{AgCl}$, and the current was continuously monitored and registered until a steady state was reached (approximately $3 \mathrm{~s}$ ). Right after, $50 \mu \mathrm{L}$ of $2.5 \times 10^{-2} \mathrm{~mol} \mathrm{~L}^{-1} \mathrm{UV}$ filter standard solution was added to the electrolytic solution and stirred for $10 \mathrm{~s}$ for solution homogenization. Then the current was monitored in the quiescent solution for $10 \mathrm{~s}$. Thus, successive additions 
of the UV filter standard solutions were performed, in order to obtain the analytical curve.

\section{HPLC analyses}

The chromatographic analyses were performed in a Shimadzu ${ }^{\circledR}$ model 20A liquid chromatograph coupled with SPD-20A UV/Vis detector, SIL-20A auto sampler and a DGU-20A 5 degasser, and monitored by a microcomputer. The column used was a C18 (250 4.6 mm, Shim-Pack CLC-ODS) fixed inside a Shimadzu ${ }^{\circledR}$ CTO-10AS oven to keep the temperature constant.

Due to the lack of an official analytical procedure for 4-MBC quantification, the procedure reported in the literature $^{39}$ was adapted and optimized by preparing the mobile phase with a mixture of acetonitrile and water in a volume ratio of 93:7. The flow rate was $1.0 \mathrm{~mL} \mathrm{~min} \mathrm{~m}^{-1}$ and the injection sample volume was $30 \mu \mathrm{L}$. The column temperature was maintained at $30{ }^{\circ} \mathrm{C}$. The measurement wavelength was $321 \mathrm{~nm}$ and the analysis time was $15 \mathrm{~min}$ for each standard and sample.

\section{Sunscreen analyses}

Child commercial sunscreens and a Lanette anionic gel-cream sample were analyzed. Before each analysis, the sample was pre-treated according to the procedure established by the Brazilian sanitary surveillance agency (ANVISA - Agência Nacional de Vigilancia Sanitária). ${ }^{40}$ For this, $2.0 \mathrm{~g}$ of the sunscreen was mixed with $4.0 \mathrm{~mL}$ of methanol and $250.0 \mu \mathrm{L}$ of $1.0 \mathrm{mmol} \mathrm{L}^{-1} \mathrm{H}_{2} \mathrm{SO}_{4}$, heated at $40{ }^{\circ} \mathrm{C}$ for $10 \mathrm{~min}$ and finally sonicated for $3 \mathrm{~min}$. After this pre-treatment, the solution was filtered and injected in the chromatograph or introduced in the electrochemical cell for the measurements.

\section{Aquatic sample analyses}

Two water samples from swimming pools and five samples collected from rivers near to the city of Araraquara, in São Paulo state, were enriched with 4-MBC and analyzed with the proposed sensor, in order to evaluate the matrix effects.

\section{Results and Discussion}

The electrochemical behaviors of the 4-MBC on the carbon paste electrode unmodified or modified with $\mathrm{FePcCl}$ are illustrated in Figure 1. The response of the unmodified paste electrode did not present any difference before and after addition of 4-MBC to the electrolyte. On the other hand, the sensor based on carbon paste modified with the iron(III) complex showed an increase in the reduction current for potentials less positive than $0.12 \mathrm{~V}$, with a maximum at around $0.0 \mathrm{~V}$ vs. $\mathrm{Ag} \mid \mathrm{AgCl}$. In addition, in absence of the analyte in the electrolyte, it was possible to observe a peak at approximately $0.1 \mathrm{~V}$, which can be associated to the $\mathrm{Fe}^{3+} / \mathrm{Fe}^{2+}$ redox couple and recognized as the catalytic site for the sensor response.

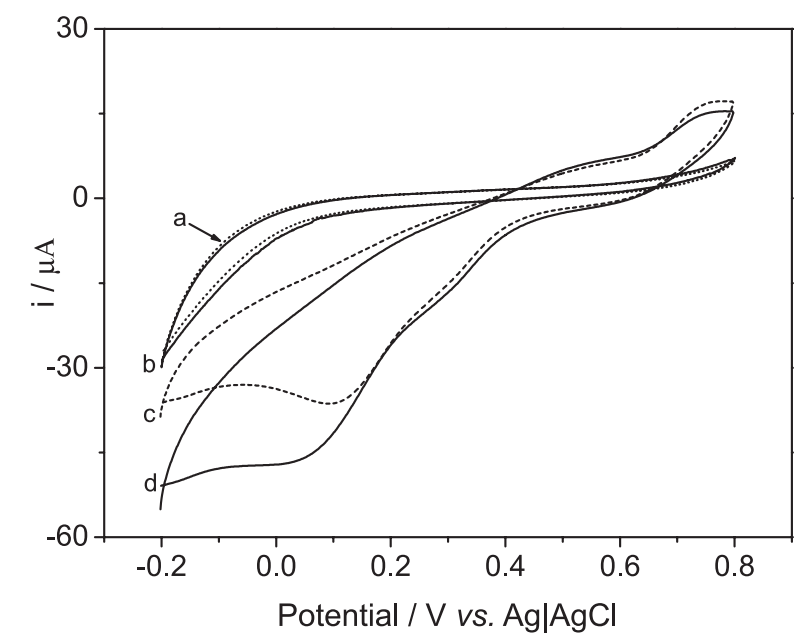

Figure 1. Voltammetric profiles for unmodified (a and b) and modified carbon paste electrodes with $\mathrm{FePcCl}$ (c and d) in $0.1 \mathrm{~mol} \mathrm{~L}^{-1} \mathrm{H}_{2} \mathrm{SO}_{4}$ /thf 70:30 (v:v) solutions in presence (solid line) and absence (dashed line) of $1.0 \times 10^{-4} \mathrm{~mol} \mathrm{~L}^{-1} 4-\mathrm{MBC}$. Potential scan rate: $20 \mathrm{mV} \mathrm{s}^{-1}$.

The dependence of the sweep rate-normalized current density $\left(\Delta \mathrm{I}_{\mathrm{p}} \mathrm{v}^{-1 / 2}\right)$ with the potential sweep rate $(\mathrm{v})$ is shown in Figure 2. The plot shape is characteristic of a typical electrocatalytical reduction process, ${ }^{35,36,41}$ indicating that the sensor response is carried out first by a chemical reaction between the analyte and the iron complex (catalyst) and further by an electrochemical process involving the

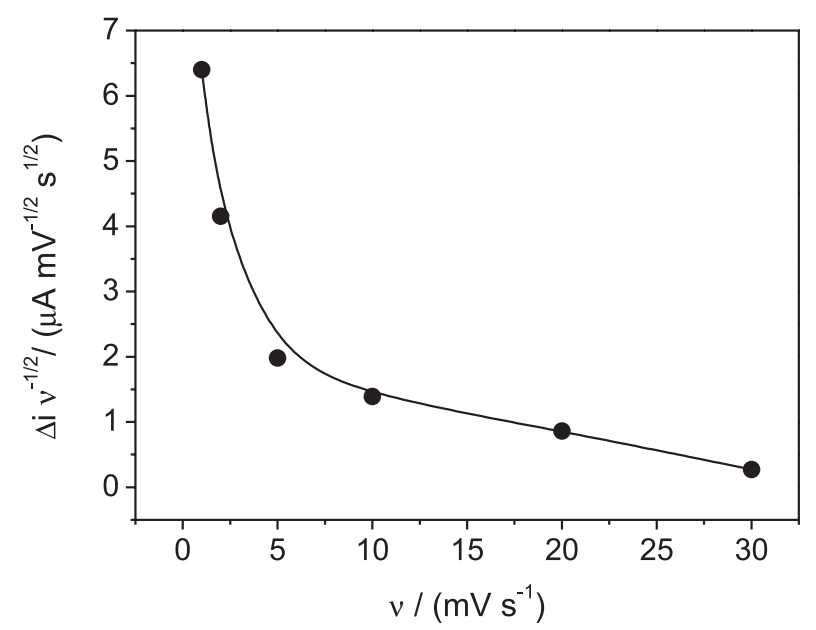

Figure 2. Plot of the sweep rate-normalized current density $\left(\Delta \mathrm{I}_{\mathrm{p}} \mathrm{v}^{-1 / 2}\right)$ versus the sweep rate $(v)$. $[4-\mathrm{MBC}]=2.0 \times 10^{-4} \mathrm{~mol} \mathrm{~L}^{-1}$ in $0.1 \mathrm{~mol} \mathrm{~L}^{-1}$ $\mathrm{H}_{2} \mathrm{SO}_{4}$ /thf 70:30 (v:v) solution. 
catalytic site regeneration $\left(\mathrm{Fe}^{3+} / \mathrm{Fe}^{2+}\right.$ redox process), with the current being proportional to the 4-MBC concentration and associated with the reduction of ferric to ferrous ions.

On the other hand, when the response profile was investigated beyond the sensor linear range, the curve presented a hyperbolic shape (data not shown), as expected for enzymatic biosensors and biomimetic sensors that follow a Michaelis-Menten kinetic relationship. ${ }^{31,36}$ Thus, in order to evaluate the apparent Michaelis-Menten constant $\left(\mathrm{K}_{\mathrm{MM}}^{\mathrm{app}}\right)$ for the 4-MBC sensor, the Lineweaver-Burk graph was constructed (Figure 3). The obtained $\mathrm{K}_{\mathrm{MM}}^{\mathrm{app}}$ value was of $3.1 \times 10^{-4} \mathrm{~mol} \mathrm{~L}^{-1}$, which is appropriate for enzymatic and biomimetic catalysts with high analyte affinity. ${ }^{31}$

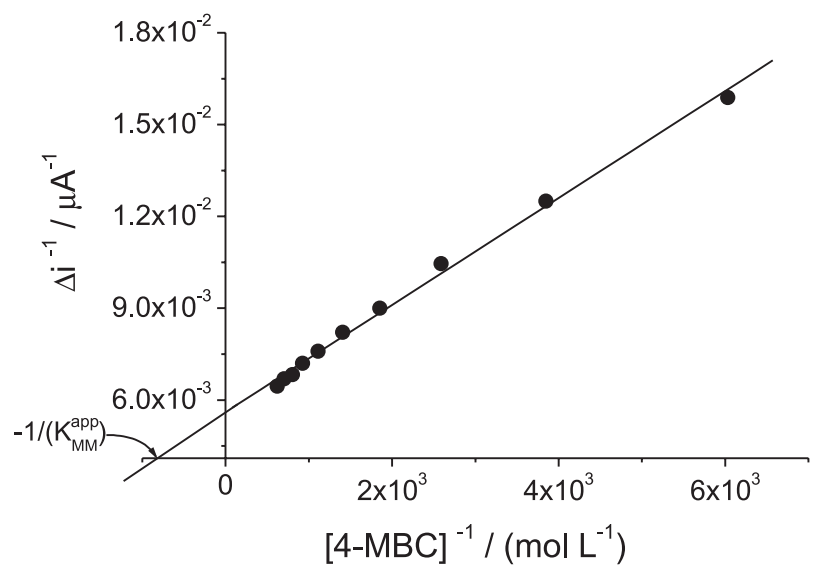

Figure 3. Lineweaver-Burk plot for the 4-MBC reduction catalyzed by the $\mathrm{FePcCl}$-based sensor.

Therefore the experimental data suggests that the $\mathrm{FePcCl}$ complex acts as a biomimetic catalyst according to the mechanism presented in Figure 4. In this mechanism, the reduction of the 4-MBC ketone group to alcohol ${ }^{41}$ via one electron in acid media promotes the oxidation of $\mathrm{Fe}^{2+}$ to $\mathrm{Fe}^{3+}$, and is followed by the regeneration of $\mathrm{Fe}^{2+}$ on the electrode surface. The mechanism also suggests that the substrate (4-MBC) reduction is favored if the ketone is a $\alpha, \beta$-unsaturated group, as demonstrated with the 10 (ten) UV filters (Figure 5) investigated in the selectivity experiments (Figure 6). It was observed that higher

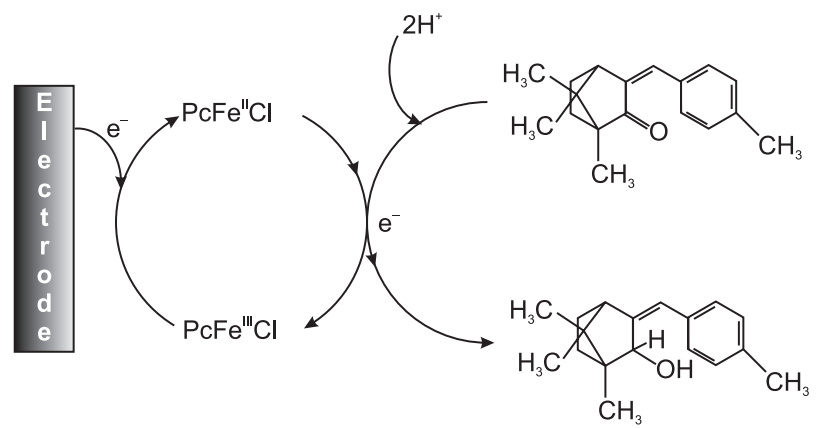

Figure 4. Mechanism proposed for the 4-MBC sensor. sensitivities are obtained with $\alpha, \beta$-unsaturated ketones, and as the unsaturation in the ketone group diminishes the sensitivity also decreases.

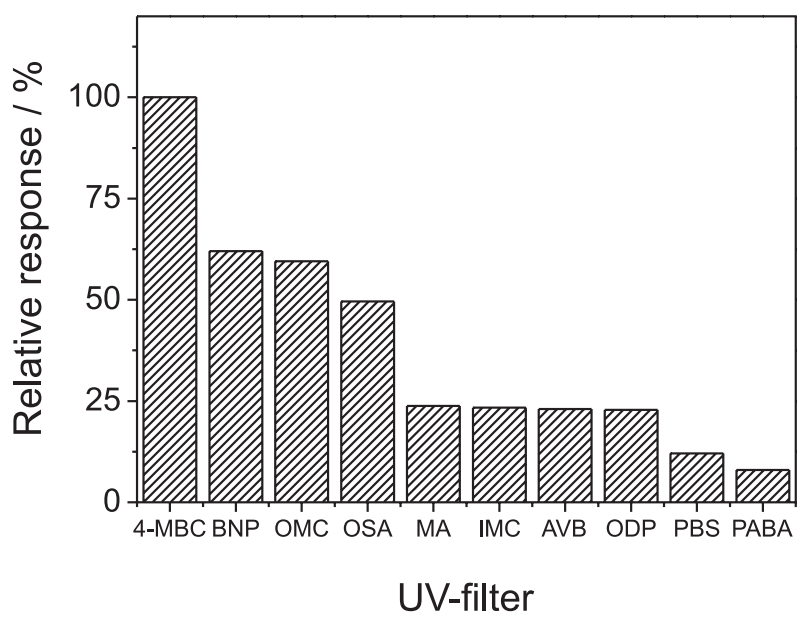

Figure 5. Relative response (\%) obtained with the FePcCl-based sensor for ten different UV filters. The parameter was calculated considering the sensor response for $4-\mathrm{MBC}$ as $100 \%$.<smiles>Cc1ccc(C=C2C(=O)C3(C)CC(C2C)C3(C)C)cc1</smiles><smiles>COc1ccc(C(=O)c2ccccc2)c(O)c1</smiles>

BNP<smiles>CCCCC(CC)COC(=O)/C=C/c1ccc(OC)cc1</smiles>

OMC<smiles>CC(=O)c1ccc(N)cc1</smiles>

MA<smiles>CCCCC(CC)COC(=O)c1ccccc1O</smiles>
OSA<smiles>CC(C)CCOC(=O)c1ccc(N(C)C)cc1</smiles><smiles>COc1ccc(C(=O)CC(=O)c2ccc(C(C)(C)C)cc2)cc1</smiles>

AVB<smiles>O=S(=O)(O)c1ccc2[nH]c(-c3ccccc3)nc2c1</smiles>

PBS

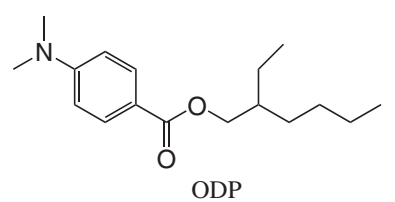<smiles>Nc1ccc(C(=O)O)cc1</smiles>

PABA

Figure 6. Chemical structures of ten UV filters evaluated in the selectivity studies. 4-MBC: 4-methylbenzylidene camphor; BNP: benzophenone-3; OMC: octyl-methoxycinnamate; OSA: octyl salicylate; MA: menthyl anthranilate; IMC: isoamyl $p$-methoxycinnamate; AVB: avobenzone; ODP: octyldimethyl-PABA; PBS: 2-phenyl-5-benzimidazolesulfonic acid and PABA: 4-aminobenzoic acid. 
Typical chronoamperometric signals and the corresponding analytical curve for 4-MBC are shown in Figure 7. The applied potential of $0.0 \mathrm{~V}$ vs. $\mathrm{Ag} \mid \mathrm{AgCl}$ was prior optimized in the potential range from -0.1 up to $+0.1 \mathrm{~V} v$ s. $\mathrm{Ag} \mid \mathrm{AgCl}$ at intervals of $0.025 \mathrm{~V}$ (data not shown). The higher sensitivity obtained at $0.0 \mathrm{~V}$ is in agreement with the voltammetric profile (Figure 2), in which the higher current variation was observed at $0.0 \mathrm{~V}$ vs. $\mathrm{Ag} \mid \mathrm{AgCl}$. It is important to emphasize that, for sensor construction, potentials close to this value are preferred in order to minimize possible interferences from other electrochemically active compounds.

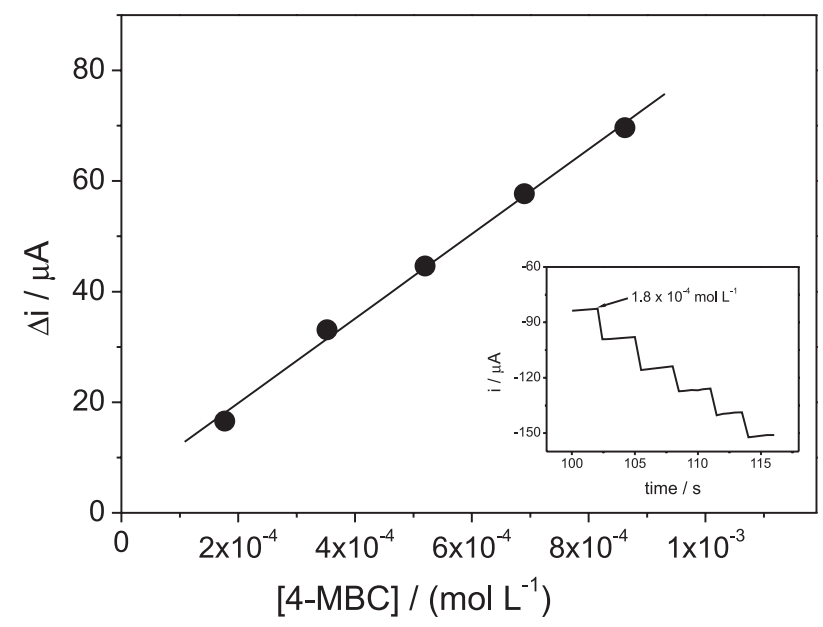

Figure 7. Typical analytical curve profile of the $\mathrm{FePcCl}$ sensor for 4-MBC under optimized conditions. Inset: chronoamperometric measurement for successive additions of the analyte.

The electrolyte solution consisted of a mixture of $0.1 \mathrm{~mol} \mathrm{~L}^{-1} \mathrm{H}_{2} \mathrm{SO}_{4}$ and tetrahydrofuran (thf) with a 70:30 optimized volume ratio. The experiments showed that, for $7.00 \mathrm{~mL}$ of this electrolyte, at least ten successive additions of $500 \mu \mathrm{L}$ of the standard UV filter solution (solubilized in thf) could be carried out without phase separation. In addition, when other acid or buffer solutions were tested no satisfactory responses were obtained, indicating the important role of $\mathrm{H}^{+}$ions in the sensor response, as suggested in the proposed mechanism (see Figure 4).

The influence of the $\mathrm{FePcCl}$ content in the carbon paste was also evaluated for the analytical sensor response and the results (Table 1) showed that $12.5 \%$ gives the highest sensitivity for 4-MBC detection.

After optimization of the parameters involved in the sensor preparation and chronoamperometric measurements, the analytical parameters for 4-MBC quantification were evaluated and are summarized in Table 2. The detection and quantification limits were calculated as suggested by the IUPAC recommendations. ${ }^{43}$ The repeatability of the measurements was estimated by plotting seven successive
Table 1. Dependence of the sensor response on the amount of $\mathrm{FePcCl}$ in the carbon paste. Measurements carried out in $0.1 \mathrm{~mol} \mathrm{~L}-1 \mathrm{H}_{2} \mathrm{SO}_{4} /$ thf solutions with 70:30 volume ratio. Applied potential: $0.0 \mathrm{~V}$ vs. $\mathrm{Ag} \mid \mathrm{AgCl}$

\begin{tabular}{cc}
\hline FeClPc amount $(\%)$ & Sensitivity $\left.(\mu \mathrm{A} \mathrm{L} \mathrm{mol})^{-1}\right)$ \\
\hline 5.0 & $3.5 \times 10^{3}$ \\
7.5 & $8.4 \times 10^{3}$ \\
10.0 & $6.3 \times 10^{4}$ \\
12.5 & $7.6 \times 10^{4}$ \\
15.0 & $2.6 \times 10^{4}$ \\
\hline
\end{tabular}

analytical curves in the corresponding linear range of the sensor. In this case, the repeatability was defined in terms of the relative standard deviation (RSD) from seven sensitivities. The reproducibility of the sensor was estimated in terms of the RSD for sensitivities calculated for five sensors prepared and used on different days by two experimentalists in different laboratories.

Table 2. Analytical parameters for 4-MBC determination on the proposed sensors based on carbon paste modified with $\mathrm{FePcCl}$

\begin{tabular}{lc}
\hline Parameter & Response \\
\hline Linear range $\left(\mathrm{mol} \mathrm{L}^{-1}\right)$ & 1.8 to $9.0 \times 10^{-4}$ \\
Sensitivity $\left(\mu \mathrm{A} \mathrm{L} \mathrm{mol}{ }^{-1}\right)$ & $76308 \pm 2505$ \\
Correlation coefficient & 0.9984 \\
Detection limit $(\mu \mathrm{mol} \mathrm{L}-1)$ & 14 \\
Quantification limit $\left(\mathrm{mol} \mathrm{L}^{-1}\right)$ & $0.5 \times 10^{-4}$ \\
Response time $(\mathrm{s})$ & 0.5 \\
Measurement repeatability $(\%)(\mathrm{RSD}, \mathrm{n}=7)$ & 1.9 \\
Sensor reproducibility $(\%)(\mathrm{RSD}, \mathrm{n}=5)$ & 1.8 \\
\hline
\end{tabular}

The proposed sensor was tested for UV filter quantification in three commercial sunscreen formulations (denoted as 1, 2 and 3) used by children in Brazil. The concentrations were determined by the sensor using the external calibration method and compared with those obtained with the chromatographic method (Table 3). One can see that that the results are not significantly different at a confidence level of $95 \%$, and it is possible to emphasize that both methods offer similar relative standard deviation values. Such data suggest an excellent sensor precision and the methodology as an efficient and rapid alternative for sunscreen analyses.

In order to verify if the sensor could be applied to aquatic environments, water samples from two private swimming pools (samples A and B) and five rivers close to Araraquara city (SP, Brazil) were analyzed after enrichment with 4-MBC. The good recovery results (Table 4), with values close to $100 \%$ for the swimming pool samples and lower values but still acceptable for the river samples, 
Table 3. Determination of 4-MBC in sunscreen samples using the sensor based on FePcCl modified carbon paste; the chromatographic method was employed as reference

\begin{tabular}{lcccc}
\hline Sample & \multicolumn{3}{c}{ UV filter concentration in \% (m/m) } & \multirow{2}{*}{ Error / \% } \\
\cline { 2 - 4 } & Label value & Comparative method (HPLC) & Proposed sensor & 3.8 \\
\hline Sunscreen 1 & 6.0 & 7.8 & 8.1 & 2.9 \\
Sunscreen 2 $^{\mathrm{b}}$ & 6.0 & 6.9 & 7.1 & 8.9 \\
Sunscreen 3 $^{\mathrm{c}}$ & 8.0 & 8.5 & 8.9 & 4.7 \\
\hline
\end{tabular}

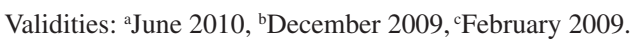

Table 4. Recovery of 4-MBC using the proposed sensor in water samples from swimming pools and rivers

\begin{tabular}{lccc}
\hline Sample & \multicolumn{2}{c}{ 4-MBC $\left(\mathrm{mol} \mathrm{L}^{-1}\right)$} & \multirow{2}{*}{ Recovery $(\%)$} \\
\cline { 2 - 3 } & Added & Found & 97 \\
Swimming pool A & $2.00 \times 10^{-4}$ & $1.94 \times 10^{-4}$ & 98 \\
Swimming pool B & $2.00 \times 10^{-4}$ & $1.96 \times 10^{-4}$ & 93 \\
Jacaré Pepira river & $2.00 \times 10^{-4}$ & $1.86 \times 10^{-4}$ & 90 \\
Jacaré Guaçú river & $2.00 \times 10^{-4}$ & $1.80 \times 10^{-4}$ & 95 \\
Jaú river & $2.00 \times 10^{-4}$ & $1.90 \times 10^{-4}$ & 91 \\
Tietê river in the limit with the Igaraçu city & $2.00 \times 10^{-4}$ & $1.82 \times 10^{-4}$ & 88 \\
Tietê river under the bridge in Barra Bonita city & $2.00 \times 10^{-4}$ & $1.76 \times 10^{-4}$ & \\
\hline
\end{tabular}

indicated that the sensor was successfully applied in the direct analyses of such water samples.

\section{Conclusion}

This work described an alternative methodology for the determination of the chemical UV filter 4-MBC on a sensitive and selective amperometric sensor based on a carbon paste modified with $\mathrm{FePcCl}$. The sensor was satisfactorily applied in sunscreen and water samples from swimming pools and rivers and it opens up real possibility for UV filter quantification in other aquatic environments, such as sewage effluents and wastewater from treatment plants.

\section{Acknowledgments}

The authors gratefully acknowledge financial support from the Brazilian agencies CNPq, ABN/Banco Real and FAPESP. A. C. B. is also indebted to ABN Bank/Banco Real for a fellowship.

\section{References}

1. Eriksson, E.; Andersen, H. R.; Ledin, A.; Water, Air, Soil Pollut.: Focus 2008, 8, 473.

2. Schlumpf, M.; Jarry, H.; Wuttke, W.; Ma, R.; Lichtensteiger, W.; Toxicology 2004, 199, 109.
3. Schmitt, C.; Oetken, M.; Dittberner, O.; Wagner, M.; Oehlmann, J.; Environ. Pollut. 2008, 152, 322.

4. Maerkel, K.; Durrer, S.; Henseler, M.; Schlumpf, M.; Lichtensteiger, W.; Toxicol. Appl. Pharmacol. 2007, 218, 152.

5. Ma, R.; Cotton, B.; Lichtensteiger, W.; Schlumpf, M.; Toxicol. Sci. 2003, 74, 43.

6. Kunz, P. Y., Fent, K.; Aquatic Toxicol. 2006, 79, 305.

7. Li, W.; Ma, Y.; Guo, C.; Hu, W.; Liu, K.; Wang, Y.; Zhu, T.; Water Res. 2007, 41, 3506.

8. Basova, T.; Plyashkevich, V.; Hassan, A.; Gurek, A. G.; Gumus, G.; Ahsen, V.; Sens. Actuators, B 2009, 139, 557.

9. Singh, S.; Tripathi, S. K.; Saihi, G. S. S.; Mater. Chem. Phys. 2008, 112, 793.

10. El-Basaty, A. B.; El-Brolossy, T. A; Abdalla, S.; Negm, S.; Abdella, R. A; Talaat, H.; Surf. Interface Anal. 2008, 40, 1623.

11. Krasnovsky Jr., A. A.; Stremedlovskaya, V. S.; Surf. Interface Anal. 2008, 12, 1194.

12. Gao, Z. X.; Li, H. F.; Liu, J.; Lin, J. M.; Anal. Chim. Acta 2008, 621,143

13. Sutarlie, L.; Yang, K. L.; Sens. Actuators, B 2008, 134, 1000.

14. Kilinç, N.; Atilla, D.; Ozturk, S.; Gurek, A. G.; Ozturk, Z. Z.; Ahsen, V.; Thin Solid Films 2009, 517, 6206.

15. Bohrer, F. I.; Colesniuc, C. N.; Park, J.; Ruidiaz, M. E.; Schuller, I. K.; Kummel, A. C.; Trogler, W. C.; J. Am. Chem. Soc. 2009, $131,478$.

16. Bohrer, F. I.; Colesniuc, C. N.; Park, J.; Schuller, I. K.; Kummel, A. C.; Trogler, W. C.; J. Am. Chem. Soc. 2008, 130, 3712. 
17. Maldonado, S.; García,-Berríos, E.; Woodka, M. D.; Brunschwig, B. S.; Lewis, N. S.; Sens. Actuators, B 2008, 134, 521.

18. El-Basaty, A. B.; El-Brolossy, T. A; Abdalla, S.; Negm, S.; Abdella, R. A; Talaat, H.; Surf. Interface Anal. 2008, 40, 1623.

19. Olivati, C. A.; Riul Jr., A.; Balogh, D. T.; Oliveira Jr, O. N.; Ferreira, M.; Bioprocess. Biosyst. Eng. 2009, 32, 41.

20. Hongkachern, T.; Suwannet, W.; Jaisutti, R.; Pratontep, S.; Osotchan, T.; Adv. Mater. Res. 2008, 55-57, 305.

21. Palaniappan, Al.; Moochhala, S.; Tay, F. E. H.; Su, X.; Phua, N. C. L.; Sens. Actuators, B 2008, 129, 184.

22. Pillay, J.; Ozoemena, K. I.; Electrochim. Acta 2009, 54, 5053.

23. Gilbert, L.; Jenkins, A. T. A.; Browning, S.; Hart, J. P.; Anal. Biochem. 2009, 393, 242.

24. Lin, Z.; Chen, Z.; Liu, Y.; Wang, J.; Chen, G.; Analyst 2008, 133,797

25. Koca, A.; Electrochem. Comm. 2009, 11, 838.

26. Koca, A.; Int. J. Hydrogen Energy 2009, 34, 2107.

27. El-Nemma, E. M.; Badawi, N. M.; Hassan, S. S. M.; Talanta 2009, 78, 723.

28. Kamel, A. H.; Almeida, S. A.; Sales, M. G.; Moreira, F. T.; Anal. Sci. 2009, 25, 365.

29. Hassan, S. S. M.; Kelany, A. E.;Al-Mehrezi, S. S.; Electroanalysis 2008, 20, 438.

30. Santhosh, P.; Joseph, M.; Sens. Actuators, B 2009, 140, 439.

31. Sotomayor, M. D. P. T.; Tanaka, A. A.; Freire, R. S.; Kubota, L. T. In Encyclopedia of Sensors, Grimes, C. A.; Dickey, E. C.; Pishko, M. V., eds., American Scientific Publishers: California, 2006, vol. 1, ch. 3 .

32. Sotomayor, M. D. P. T.; Kubota, L. T.; Quim. Nova 2002, 25, 123.

33. Ozcan, L.; Sahin, Y.; Turk, H.; Biosens. Bioelectron. 2008, 24, 512.
34. Damos, F. S.; Sotomayor, M. D. P. T.; Kubota, L. T.; Tanaka, S. M. C. N.; Tanaka, A. A.; Analyst 2003, 128, 255.

35. Sigoli, A.; Lanza, M. R. V.; Tanaka, A. A.; Kubota, L. T.; Sotomayor, M. D. P. T.; J. Braz. Chem. Soc. 2008, 19, 734.

36. Batista, I. V.; Lanza, M. R. V.; Dias, I. L. T.; Tanaka, S. M. C. N.; Tanaka, A. A.; Sotomayor, M. D. P. T.; Analyst 2008, 133, 1692.

37. Santos, W. J.; Sousa, A. L.; Sotomayor, M. D. P. T.; Damos, F. S.; Tanaka, S. M. C. N.; Kubota, L. T.; Tanaka, A. A.; J. Braz. Chem. Soc. 2009, 20, 118.

38. Sotomayor, M. D. P. T.; Tanaka, A. A.; Kubota, L. T.; Anal. Chim. Acta 2002, 455, 215.

39. Völkel, W.; Colnot, T.; Schauer, U. M. D.; Broschard, T. H.; Dekant, W.; Toxicol. Appl. Pharmacol. 2006, 216, 331.

40. Agência Nacional de Vigilância Sanitária; Guia de Controle de Qualidade de Produtos Cosméticos: Uma Abordagem sobre os Ensaios Físicos e Químicos, ANVISA Editora: Brasília, 2007, http://portal.anvisa.gov.br/wps/wcm/connect/5b2fab80407ca3 518d6ded42f89e3ba5/guia_cosmetico.pdf?MOD=AJPERES, in Portuguese.

41. Bard, A. J.; Faulkner, L. R.; Electrochemical Methods: Fundamentals and Applications, $2^{\text {nd }}$ ed., John Wiley \& Sons, Inc.: New York, 2001.

42. Smith, M. B.; Organic Synthesis, McGraw-Hill: New York, 1994.

43. Currie, A.; Anal. Chim. Acta 1999, 391, 105.

Received: September 14, 2009

Web Release Date: May 4, 2010

FAPESP helped in meeting the publication costs of this article. 